
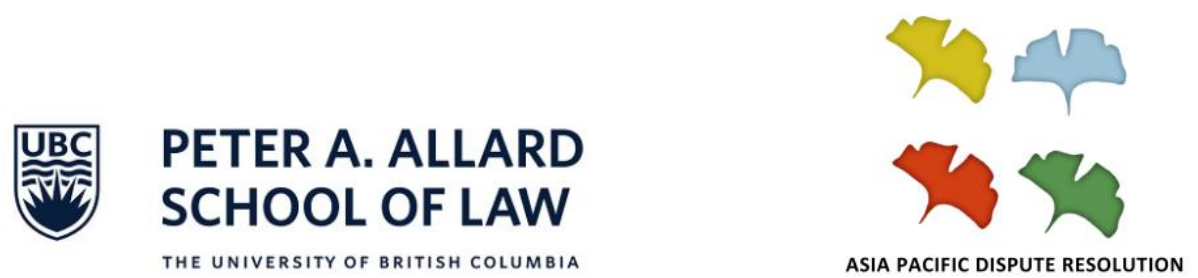

\title{
The Green Leap Forward? Precarious Labour in a Greening China A.T. Kingsmith York University
}

APDR Working Paper Series

Volume 4 Number 2

ISSN 2371-6304

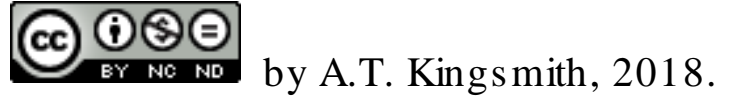

This article is made available as part of the As ia Pacific Dispute Resolution Working Paper Series and is licensed under a Creative Commons Attribution-

NonCommercial-NoDerivatives 4.0 International License

$$
\text { (CC-BY-NC-ND) }
$$




\title{
THE GREEN LEAP FORWARD? PRECARIOUS LABOUR IN A GREENING CHINA
}

\author{
A.T. Kingsmith* \\ York University
}

\section{Introduction}

In accordance with its commitments to Paris Climate Accord, China's trade agreements and policy initiatives under the framework of the One Belt, One Road Initiative (OBOR) have taken a more flexible approach and showed greater willingness to prioritize substantive environmental provisions. However, recent attempts by China to bring its heavy industries in line with these new environmental regulations and to initiate a sustained effort to move towards a greener economy has resulted in the laying off of thousands of heavy industry workers (Gao, 2017). In an attempt to address this problem, China has initiated a transition towards an economy with a larger service industry, which the government claims, will "help facilitate a joint strategy of stringent pollution control combined with job growth" (Pan, 2016).

This working paper builds upon empirical research from a forthcoming book project titled One Road, Many Dreams (Drache, Kingsmith, and Qi) to examine tensions between China's increasingly comprehensive environmental provisions and its labour policies in the context of China's shifting expenditures from the production to services. To this end, it discusses President Xi's vision of "the ecological civilization" in relation to benchmark environment and labour provisions to highlight the ways China maintains an inflexible position on labour rights, while also positioning itself as a leader against environmental degradation. It concludes with the increasing strain between precarious work and a "greening China" by surveying how China's present environmental ambitions are plagued by a series of labour problems that could negatively affect Xi's vision for an

\footnotetext{
* The following text was presented at the "Asia Pacific Dispute Resolution - Coordinating Performance in International Trade and Human Rights" Symposium held at The University of British Columbia, Peter A. Allard School of Law, Vancouver, Canada on 27 October 2017 (Panel 2: Trade Policy and Labour).
} 
ecological civilization unless the Party starts to take seriously what Sara Swider (2015a, 6) refers to as new models of "employment configuration."

\section{The Ecological Civilization}

Speaking at the opening session of the 19th Communist Party Congress on 18 October 2017, President Xi turned early in his remarks to "ecological civilization." He noted that China had made major efforts to reduce consumption and save resources, and that these steps were paying off domestically_and setting an example globally.

About 15 minutes into the start of his three-hour-plus speech known as a "work report," (the remarks were accompanied by simultaneous English translation on the CGTN livestream), $\mathrm{Xi}$ made it clear that in "taking a driving seat in international cooperation to respond to climate change, China has become an important participant, contributor, and torchbearer in the global endeavour for ecological civilization" (Xinhua, 2017). Consistent with his role as a core leader, Xi's remarks on the environment at the leadership reshuffle meeting, which evaluates the previous five years and sets priorities for the next five years, were couched in much more emotional terms than those used by $\mathrm{Hu}$ Jintao at the last party congress in 2012.

"Any harm we inflict on nature will eventually return to haunt us ... this is a reality we have to face," $\mathrm{Xi}$ told the congress, adding that China must "develop a new model of modernization with humans developing in harmony with nature" (Xinhua, 2017). These remarks come as the country has increasingly focused on shifting from a reliance on fossil fuels in order to curb what some in the Chinese Academy of Sciences (2017) have called an "airpocalypse," as well as curb coal overcapacity problems. But as the drive to increase participation in the OBOR expands, China has realized that taking a leadership role in these efforts will allow it to command greater respect on the world stage, particularly as the US, under President Donald Trump, has made it clear that it is not interested in playing a role in safeguarding the environment.

This party conference helps focus our analysis on labour rights and the environment. With $\mathrm{Xi}$ acting as core leader, we see a re-orienting of priorities, not in all 
respects but in some. ${ }^{1}$ In my view (and in the view of a number of experts: Cao \& Wujin, 2014; Weng et al., 2015; UNEP, 2016), the environment has increasingly become a priority for the Party. Exploring what China's so-called "green leap forward" means for labour rights is the primary aim of this working paper. Of course, as always with China, it is difficult to be certain of all the different factors. While Xi's new green initiatives present an opportunity to make serious progress on climate change, the future of labour rights in the country remains vague and unpredictable.

\section{China and the Environment}

"We will get actively involved in global environmental governance and fulfill our emissions reductions," $\mathrm{Xi}$ added in his concluding remarks about the need to put the environment first (Xinhua, 2017). Under the Paris Accord, China, the world's biggest emitter of greenhouse gases, has pledged to cut its carbon emissions by $60 \%$ to $65 \%$ per unit of GDP by 2030, compared with 2005 levels, and to see an overall decline in emissions from 2031 on (Chen, 2016). China also has been investing in renewable energy (though according to British Petroleum's (2017) 'Statistical Review of World Energy,' this is still a small share of its overall energy mix), and subsidizing the purchasing of electric cars. In early September, China also said it planned to phase out fossil fuelpowered cars although no specific timeline has been revealed yet (Woetzel et al., 2014).

In 1978, China recognised the importance of environmental protection for the first time in its Constitution, followed by the adoption of a provisional Environmental Protection Law a year later. Over the next four decades, China gradually built up a comprehensive legal framework on environmental protection. The basic principles are laid down in the Environmental Protection Law enacted in 1989, with additional dozen

\footnotetext{
${ }^{1}$ Importantly, the term "core leader" goes back a few decades, and has been given to four leaders: Mao Zedong, Deng Xiaoping, Jiang Zemin and now Mr. Xi. As Buckley (2016) points out, Mao and Deng established their tremendous personal authority through decades of revolutionary struggle and war, while Xi's power is less personal. Modern Chinese politics has become more settled and tied to procedures, and in this way $\mathrm{Xi}$ has established himself by creating and remaking rules and institutions to magnify his power.
} 
laws addressing specific environmental problems such as ocean pollution (1992), environmental noise (1996), and solid waste (2004) (Finamore, Xu, Yan, 2014).

Early on, China's Regional Trade Agreements tended to take a cautious approach to environmental provisions. Typically, the environmental provisions in these agreements are limited to the recognition of the principle of "sustainable development" in the preamble, the inclusion of environmental measures as exceptions to trade obligations, some non-binding best endeavour language on environmental cooperation, and occasionally, market access commitments on environmental goods and services.

However, reflecting the recent commitment to build an "ecological civilization", China has taken a more flexible approach and showed greater willingness to include more substantive environmental provisions (Pan, 2016). For example, its 2017 free trade agreement (FTA) with Singapore is building the first intergovernmental eco-city in the world, which provides an interesting new model for environmental cooperation. ${ }^{2}$ Moreover, China's most recent FTAs with Switzerland (2014) and Korea (2015) go even further by including dedicated chapters on the environment that address the "enforcement problem" by requiring parties to "effectively enforce their environmental measures including laws and regulations, through a sustained or recurring course of action or inaction, in a manner affecting trade or investment between the Parties."

Provisions such as these give us a glimpse into China's willingness to engage more on environmental issues in FTAs. At the same time, none of China's agreements allow for the application of the dispute settlement mechanism to the environmental chapter, suggesting that China is still reluctant to accept its environmental commitments as binding, legally-enforceable obligations.

\footnotetext{
${ }^{2}$ An eco-city is a city built from the principles of living within environment means, the ultimate goal being to eliminate all carbon waste (zero-carbon city), to produce energy entirely through renewable resources, and to merge the city harmoniously with the natural environment. With more than 70,000 residents, 4,500 registered companies, and a total registered capital of 200 billion yuan ( $\$ 40.9$ billion), the Tianjin EcoCity is an unproven and highly ambitious attempt at stimulating "green growth" (MacKenzie, 2017).
} 


\section{China and Labour}

In contrast, China moves at the speed of a glacier with respect to labour rights. This is, as China experts point out (Chan, 2003; Zhou, 2013), a very complex area. On the one hand, China was a founding member of the International Labour Organization (ILO); however, for political reasons, it only started actively participating in the organization from 1983 (ILO, 2017). Further, as Xiaomin Yu (2008) points out, the race to ethical and legal minimum labor standards in China has resulted in notoriously inhumane and seriously illegal labor rights abuses that force Chinese workers to work harder and faster for lower and lower wages.

Though everyone in China belongs to a union - even Wal-Mart employees-as Chan and Hui (2014) point out, these unions are not what we would consider independent or autonomous (this is quite common elsewhere in the world as well: for example, Canada's NAFTA partner Mexico, with its Maquiladoras, does not have independent unions either). As Chan and Hui (2014) point out, the main barrier to effective workplace unionism in China is the lack of external support for workers' unionisation efforts. On the one hand, the lower-level local trade unions fail to comply with their legal responsibility because of their bureaucratic nature and structural integration into the patron-client relationship between the local state and international economic interests. On the other, support for workers from civil society is handicapped by the party state's opposition to independent labour organising. Rather than an autonomous workers' organization representing worker' interests, Chinese workers must rely on non-democratic trade unions installed through codes of implementation that, according to Chan and Hui (2014), function as a 'company unions': unions or worker's organizations that are dominated or influenced by an employer, and are therefore not independent trade unions.

China has signed 26 ILO conventions, including four core conventions on equal remuneration, discrimination (employment and occupation), minimum age, and child labour. This puts China well below the world average of 40 ILO conventions and seven core conventions signed by a typical country. In fairness, ILO conventions are what we call "soft law," in that they produce norms but they do not create obligations, thus very 
few countries actually uphold most of these ILO agreements. The conventions signed by China are almost all technical ones with only two governance conventions. In particular, China has not signed the conventions relating to the freedom of association, right to organize, or collective bargaining. These rights are recognised by Article 8.1 (a) of the International Covenant on Economic, Social, and Cultural Rights (ICESCR), ratified by China in 2003 with the reservation that the application of this Article "shall be consistent with the relevant provisions of the Trade Union Law of the People's Republic of China," which only recognizes the official All-China Federation of Trade Unions (China Economic Review, 2016).

Another problematic area for China is forced labour: though re-education through labour was officially abolished in 2013, prison labour remains a huge issue (Scherrer \& Shah, 2017). Beyond the ILO conventions, forced labour is prohibited by the International Covenant on Civil and Political Rights (ICCPR), which China has also yet to ratify. In line with its cautious approach, China did not include labour issues in its earlier FTAs. Instead, the issue was often addressed in stand-alone bilateral labour cooperation agreements or memorandums of understanding (MOUs) signed with its partner countries.

Since 2008, when Hu Jintao absorbed the Ministry of Labour and Social Security (MOLSS) into the Ministry of Commerce (MOFCOM), China shifted its focus from labour rights more broadly to an emphasis on labour exporting. For example, its FTAs with New Zealand (2015) and Australia (2017) include special chapters on movement of natural persons, as well as special market access opportunities for China-specific occupations such as traditional Chinese medicine practitioners, Chinese martial arts coaches, and Chinese chefs.

As the OBOR increases demands for Chinese labour, we will likely see more provisions facilitating the export of Chinese workers, such as expedited visa processing, more Mode 4 commitments, and quota expansion on China-specific occupations. However, China seems intent on maintaining its coercive, authoritarian position on restrictive labour rights and provisions, especially those relating to labour unions. 


\section{Precarious Labour in a Greening China}

The tension between expanding environmental policies and its inflexible position on labour rights may be pushed to a breaking point by China's newly self-appointed leadership role in curbing environmental degradation. Pressure has increased on local governments since September 2016, when China's Cabinet released an action plan to control and prevent air pollution through to 2019. Since then, the country's provinces have released their own plans, including new restrictions on coal and heavy industry. Moreover, the party has required local governments to constantly revise the criteria used to evaluate their officials away from economic growth to their "overall work" and contributions to the "ecological civilization" (Gao, 2017).

But shutting plants has taken a human and economic toll in lost jobs and income. The Chinese coal industry, one of the largest employers in the country, has already gone through a spurt of productivity increases, which has decreased labour intensity. Increasing modernization, coupled with the fact that the quality of the environment is now among the main criteria used to assess officials' performances, has led to the demolition or closure of over a hundred coal plants in highly polluted industrial regions (Forsythe, 2017). For instance, in Hebei's Pingshan County, about a four-hour drive southwest of Beijing, local authorities have closed 35 factories, resulting in over 4,000 workers being laid off (Jinran, 2017).

Economists working in Western markets might applaud this, but according to the lived experience of workers, it is creating significant social unrest and displacement. Of course, this kind of top-down approach to problem-solving pays immediate dividendsChina is actually closing coal plants, while Trump is taking steps to open more of them (Thomson, 2017). According to Hebei Province's Communist Party chief Sun Ruibin, closures may cause "slow economic growth in the short term, but this will work in upgrading the economic structure and result in a good living environment for our people, so it is worthwhile" (GBTimes, 2014). But as Professor Ying Zhou's (2012, 17) benchmark study of precarious work in China points out, "upgrading the economic structure" is largely bureaucracy-speak for the transition towards an economy reliant on a 
more informal service sector, which is "characterized by an uncertainty and unpredictability of employment."

This transition moves Chinese policy away from an emphasis on reforming traditional sectors mired with pollution and over production problems and towards "the ecological civilization" and its subsequent focus on new areas within the service sector, such as e-commerce and technology, which the government claims will help to facilitate a joint strategy of stringent pollution control combined with job growth (Pan, 2016).

However, as a recent study by Sarah Swider (2015b) has shown, while the reduction in industry may indeed be a form of pollution control, far from facilitating job growth, industries such as e-commerce and technology are becoming exclusive clubs for a rising middle class, while the majority of available occupations in construction, food, and cleaning services are setting the foundations for what, borrowing from Guy Standing (2011), Swider calls China's "New Precariat." 3

\section{Conclusions}

With these points in mind, I have three brief conclusions:

1. China has to consider new models: As Swider (2015a) argues in Building China, China must consider new configurations of employment to analyse its labour problems and to bring informal workers, who are operating outside of state regulations, back into an industrial labour relations framework. Such an employment re-configuration would require frameworks to refocus attention from the dyadic worker-employer relationship to the more complex triad of the worker,

\footnotetext{
${ }^{3}$ In his seminal work The Precariat (2011), Standing traces the rise of precarious work in the Global North through the disempowerment of workers and the eradication of employment stability. In doing so, he pinpoints a series of changing phenomena that lead to the casualization of employment such as the commodification of the firm, numerical and functional flexibility, job insecurity, occupational dismantling, and wage-system restructuring. He also clearly perceives that the growth in the precariousness of pay through expanding service industries is accompanied by a dismantling of the social and employment support systems such as unemployment and sickness "insurance" pay. In many ways, Swider's (2015a, 2015b) work modifies and expands Standing's "precariat" to analyze the rise of precarious work in China.
} 
the employer, and the state — shedding light on varying sources of "informal work and the new precariat in China," (Swider, 2015b, 18).

2. China will have to grapple with precarious part-time work: While the factors underlying the diffusion of precarious work in China will always be tied to changes in the structure of industry, occupations, urbanization, state policies, and labour market institutions, the correlation between intensifying environmental commitments and the potential for a dramatic increase in precarious informal work will be one to watch as China moves to further incorporate Xi's model of "the ecological civilization" into the framework of the OBOR and beyond.

3. As the service economy becomes modernized and generalized in China, it is very likely that it is going to make many of the same mistakes emphasised by Standing (2011) and expanded upon by Swider (2015b) that the universalization of the service economy did in the Global North: Although the spread of precarious work is sometimes advocated as an effective means of generating employment and increasing labour market flexibility, substantial evidence from Chinese scholars (Zhou, 2012) and from the three successive crises of inflation, public finance, and private debt—which as Piketty (2014) and Streeck (2016) point out, have called into question the stability of the Western model-show how such work is plagued by an intense climate of economic and social precarity characterised by low pay, low skill, high work intensity, poor working conditions, and a lack of employment protection. There is a definite possibility that these processes could create a new "precariat" as it has done, and is continuing to do, here in the Global North. 


\section{References}

BP Statistical Review of World Energy. "Renewable Energy." British Petroleum, June 2017. Accessed 2 December 2017, https://www.bp.com/content/dam/bp/en/ corporate/pdf/energy-economics/statistical-review-2017/bp-statistical-review-ofworld-energy-2017-full-report.pdf.

Buckley, Chris. "Xi Jinping Is China's 'Core' Leader: Here's What It Means." The New York Times, October 2016. Accessed 4 December 2017, https://www.nytimes. com/2016/10/31/world/asia/china-xi-jinping-communist-party.html.

Cao, Baoyin and Yin Wujin. Ecological Civilization of Contemporary China. Beijing: China Intercontinental Press, 2014.

Central People's Government of the People's Republic of China, The. "Environmental Protection Law of the People's Republic of China." China.org, Adopted on 26 December 1989. Accessed 2 December 2017, http://www.china.org.cn/english/ environment/34356.htm.

Chan, Anita. "A Race to the Bottom." China Perspectives, Issue 46, March-April 2003. Accessed 4 December 2017, http://chinaperspectives.revues.org/259.

Chan, Chris King-Chi and Elaine Sio-Ieng Hui. "The Dynamics and Dilemma of Workplace Trade Union Reform in China: The Case of Honda Workers' Strike.” In Xavier Richet, Violane Delteil, and Patrick Dieuaide (eds), Strategies of Multinational Corporations and Social Regulations. Berlin and Heidelberg: Springer, 2014.

Chen, Han. "The Road to Paris: China's Progress Towards It's Climate Pledge." National Resource Defence Council (NRDC), November 2016. Accessed 28 November 2017, https://www.nrdc.org/sites/default/files/paris-climate-conference-ChinaIB.pdf.

China Economic Review. “China's Workforce Faces Tough Year Shifting Gears from Manufacturing to Services." China Economic Review, 8 January 2016. Accessed 28 November 2017, http://www.chinaeconomicreview.com/chinas-workforcefaces-tough-year-shifting-gears-manufacturing-services.

Finamore, Barbara, Christine $\mathrm{Xu}$ and Wang Yan. "New Weapons in the War on Pollution: China's Environmental Protection Law Amendments." National Resource Defence Council (NRDC), 2014. Accessed 2 December 2017, https://www.nrdc.org/experts/barbara-finamore/new-weapons-war-pollutionchinas-environmental-protection-law-amendments.

Forsythe, Michael. "China Cancels 103 Coal Plants, Mindful of Smog and Wasted Capacity." The New York Times, 18 January 2017. Accessed 28 November 2017, 
https://www.nytimes.com/2017/01/18/world/asia/china-coal-power-plantspollution.html.

Gao, Henry. "China's Evolving Approach to Environmental and Labour Provisions in Regional Trade Agreements." International Centre for Trade and Sustainable Development, 25 August 2017. Accessed 28 November 2017, https://www.ictsd.org/opinion/china-3.

GBTIMES Beijing. "Hebei Province Tears Down 17 Cement Plants to Fight Air Pollution." GBTIMES, 18 February 2014. Accessed 28 November 2017, https://gbtimes.com/hebei-province-tears-down-17-cement-plants-to-fight-airpollution.

International Labour Organization (ILO). "Conventions and Protocols." ILO, 2017. Accessed 28 November 2017, https://www.ilo.org/dyn/normlex/ en/f?p=NORMLEXPUB:12000:0::NO:::.

Jinran, Zheng. "Inspections Put Pressure on Polluters in 28 Cities." China Daily, 4 May 2017. Accessed 28 November 2017, http://www.chinadaily.com.cn/china/201705/04/content_29195507.htm.

MacKenzie, Derek. "Green Buildings, Singapore's Natural Ally in Climate Change Fight." Eco-Business, November 2017. Accessed 4 December 2017, http://www.eco-business.com/opinion/green-buildings-singapores-natural-ally-inclimate-change-fight/.

Pan, Jiahua. China's Environmental Governing and Ecological Civilization. Heidelberg: Springer-Verlag GmbH, 2016.

Piketty, Thomas. Capital in the Twenty-First Century. Cambridge, MA: Harvard University Press, 2014.

Scherrer, Christoph and Anil Shah. "The Political Economy of Prison Labour: From Penal Welfarism to the Penal State." Global Labour Journal 8:1 (2017), 32-48.

Standing, Guy. The Precariat: The New Dangerous Class. New York: A\&C Black, 2011.

Streeck, Wolfgang. How Will Capitalism End? Essays on a Failing System. London: Verso Books, 2016.

Swider, Sarah. "Building China: Precarious Employment among Migrant Construction Workers." Work, Employment and Society 29:1 (2015a), 41-59.

Swider, Sarah Christine. Building China: Informal Work and the New Precariat. Ithaca, NY: Cornell University Press, 2015b. 
Thomson, Vivian E. "Trump's Breathtaking Hypocrisy on Coal Mining." Scientific American, 22 September 2017. Accessed 4 December 2017, https://blogs.scientificamerican.com/observations/trumps-breathtaking-hypocrisyon-coal-mining/.

United Nations Environment Programme (UNEP). "Green is Gold: The Strategy and Actions of China's Ecological Civilization." United Nations Environment Programme, 2016. Accessed 28 November 2017, https://reliefweb.int/sites/ reliefweb.int/files/resources/greenisgold_en_20160519.pdf.

University of Chinese Academy of Sciences. "International Symposium on Pollution and Human Health.” 29 May-1 June 2017. Accessed 28 November 2017, http://english.ucas.ac.cn/index.php/events/4633-international-symposium-on-airpollution-and-human-health.

Wall Street Journal. "Life Inside Foxconn's Facility in Shenzhen." Wall Street Journal, 19 December 2012. Accessed 28 November 2017, https://blogs.wsj.com/ chinarealtime/2012/12/19/life-inside-foxconns-facility-in-shenzhen/.

Weng, Xiaoxue, Zhanfeng Dong, Qiong Wu and Ying Qin. China's Path to a Greening Economy: Decoding China's Green Economy Concepts and Policies. International Institute for Environment and Development, 2015. Accessed 28 November 2017, http://group-global.org/sites/default/files/publications/China's $\% 20$ path\%20to\%20a\%20green\%20economy.pdf.

Woetzel, Jonathan, Oliver Tonby, Fraser Thompson, Penny Burtt, and Gillian Lee. "Three Paths to Sustained Economic Growth in Southeast Asia." McKinsey \& Company, 2014. Accessed 28 November 2017, http://www.mckinsey.com/globalthemes/asia-pacific/three-paths-to-sustained-economic-growth-in-southeast-asia.

Yu, Xiaomin. "Impacts of Corporate Code of Conduct on Labor Standards: A Case Study of Reebok's Athletic Footwear Supplier Factory in China." Business Ethics, 81: 513,2008 .

Xinhua. "Full Text of Xi Jinping's Report at 19th CPC National Congress." Xinhua Daily News, 3 November 2017. Accessed 28 November 2017, http://news.xinhuanet.com/english/special/2017-11/03/c_136725942.htm.

Zhou, Ying. "The State of Precarious Work in China." American Behavioural Scientist 57:3 (2013), 354-372. 